\title{
Editorial
}

\section{Concerns of an Editor for the Diabetologist}

Two problems are on the rise, it seems to me: obesity and information. The former is taking on the size of an epidemic [1], and not only in the westernised part of the world: even in the remainder of the planet, the majority of humans starve, the happy few get fat. Molecular biology tells us that the obese gene may be to blame [2], or that its product, leptin, may be the culprit [3]. This is a very interesting story, and there is certainly much to be learned from it. However, genes evolve slowly (a chance every $\sim 20$ years). For example, in a survey of 40 alleles of 7 blood groups (ABO, Rh, MNS, Kell, HP, HLAA, and HLAB) in the Italian population [4], principal component analysis generated a map of gene frequencies that was impressively superimposable on the known distribution of the pre-Roman nations inhabiting the peninsula (mostly, Greeks in the south, Etruscans in the centre, Venetics in the north-east, Ligurians in the northwest). This means that the vast majority of the genome prevailing in present-day Italy has been little disturbed by the many uninvited guests (German, Goth, Swabian, French, Spanish, Arab) visiting the place over the last couple of millennia. Thus, the reluctance of genes to change cannot explain the galloping tempo of obesity. This, evidently, must be the result of environmental changes (in diet and/or physical activity), or the usual conspiracy between genes and environment. Weight gain is a chronically positive energy balance, with intake exceeding dissipation. Being energy efficient may have been an evolutionary advantage, conservation of unrequired energy is obesity. More broadly, obesity is a heterologous energy exchange: we save as triglycerides what our car burns as gasoline. In the trade off, not only do we gain chemical pollution but we also strain the endocrine pancreas: diabetes risk rises exponentially with increasing body weight [5]. There is enough for the obese person to worry about, and to keep the diabetologist busy.
Information is key for life. Indeed, the genome is an information system in which the DNA filament is the text and RNA polymerase is the copier. Development of a relatively simple code, capable of packaging huge amounts of instructions (the $\sim 100,000$ genes) in a relatively slim physical support (the handful of chromosomes), has meant a formidable saving of time for the evolution of complex cellular functions. In fact, the thermodynamics of information theory ( $\mathrm{I}$ am told) is such that loss of information increases entropy, whilst information storage saves energy. Even parallel calculus (cf. the latest fancy computers they are trying to sell us) is based on the fact that assigning separate tasks to multiple calculating units saves time as long as intermediate results can be stored and transferred between units. The ability to acquire and process information confers evolutionary advantage to all living creatures. Actually, human language, a chief tool of information, has evolved to the status of a true instinct [6]. Yet, we live in times of excessive information, carried on paper, tape or disk, plus an airborne flood of waves, repeated by antennas, bouncing off satellites, eventually seeping through all kinds of media to demand our attention. This overload of information steals time from other assignments, and stores unnecessary energy. Thermodynamically, it is obesity. Like abdominal obesity, in which the fat surplus ends up in dangerous spots (i.e. in the viscera), errors propagate easily when information is uncontrollably large. If obesity is the substrate of excessive cardiovascular risk, information overload can depress logical functions, stun creativity, and eventually foster a secondary form of ignorance.

In our profession, we are supposed to scan (read, hear or watch) vast repositories of information to keep abreast with knowledge on just one disease. The situation is aggravated by the fact that diabetes is increasingly a systemic disease, not only because its complications affect many organs but because 
multiple abnormalities appear to contribute to its development (cf. the insulin resistance syndrome). As a student, less than 20 textbook pages on diabetes led me safely through the internal medicine examination; as a postgraduate student, $\mathrm{I}$ had to peruse a ponderous treatise to get my subspecialty degree; nowadays, I unashamedly contribute hefty chapters on a peculiar aspect of a branch of the pathogenesis of just one kind of diabetes. These products become ramparts in my curriculum vitae, and please my ego. Whether they are of any use to any colleague, however, I honestly do not know. Furthermore, I recently found out that, on updating some chapter I had written only a few years previously, I had forgotten sizeable parts of it, sometimes the very rationale of some passage. Worried, I began debating to myself whether this phenomenon was due to informational brain damage, sheer mental senescence, or to editing Diabetologia for two years. It then occurred to me that memory was probably doing a good job, the right job, in deleting blocks of unconvinced or unnecessary information from my current operational menu. In the process, some good or useful bit may also be washed down the drain, but it is hygiene nevertheless. It makes room to learn more, or to be surprised again, or to be ever curious.

Thus, information overload and obesity are not just a metaphor for each other. Because of their common thermodynamic basis, they can easily build perverse feedback loops between them. Thus, by sitting long hours before a TV screen children are imbued with commercial commonplace and accumulate calories. In the meantime, some of their parents are planning to replace books and journals with electronic equivalents (the E-journals [7]), with the predictable consequence of suppressing the energy-consuming habit of browsing around libraries (looking for a reference, a notion, an inspiration, or nothing).

For obesity and information excess, there are no solutions, it seems to me, but only controlled problems. For example, we can increase our efforts to re- duce obesity in our diabetic patients also by keeping information simple and concise, i.e. applying a dual energy diet. More in general, we might re-think our sense of time. It is common experience that by constantly striving to save time we are constantly short of time. We may want to invest a bit in slowness or idleness (or silence). On the worn-out dial of my old pendulum-clock, I thought a Latin engraving said Tempus fugit (time runs away). On closer look, it actually says Tempus fugite (run away from time): how much more sense with just a final $e$, how much wisdom in just two words of an obsolete language.

\section{Happy New Year.}

Ele Ferrannini

Pisa, 1 January 1996

\section{References}

1. Kuczmarski RJ, Flegal KM, Campbell SM, Johnson CL (1994) Increasing prevalence of overweight among US adults. The National Health and Nutrition Examination Surveys, 1960 to 1991. JAMA 272: 205-211

2. Zhang Y, Proenca R, Maffei M, Barone M, Leopold L, Friedman MJ (1995) Positional cloning of the mouse obese gene and its human homologue. Nature 372: 425-432

3. Halaas JL, Gajiwala KS, Maffei M et al. (1995) Weight reducing effects of the plasma protein encoded by the obese gene. Science 269: 543-546

4. Piazza A, Cappello N, Olivetti E, Rendine S (1988) A genetic history of Italy. Ann Hum Genet 52: 203-213

5. Perry IJ, Wannamethee SG, Walker MK, Thomson AG, Whincup PH, Shaper AG (1995) Prospective study of risk factors for development of non-insulin dependent diabetes in middle aged British men. BMJ 310: 560-564

6. Pinker S (1994) The language instinct. How the mind creates language. William Morrow \& Company, Inc., New York

7. Okerson A (Ed) (1994) Directory of electronic journals, newsletters and academic discussion lists. Association of Research Libraries, Office of Scientific and Academic Publishing 